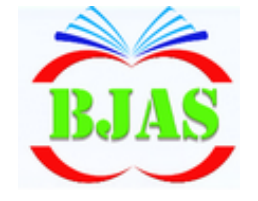

ISSN $1814-5868$
Available online at http://bjas.bajas.edu.iq https://doi.org/10.37077/25200860.2021.34.1.16 College of Agriculture, University of Basrah

Basrah J. Agric. Sci., 34(1), 180-191, 2021

\section{Basrah Journal of Agricultural Sciences}

E-ISSN: 2520-0860

\title{
Polymorphism of LEP and TNF- $\alpha$ Genes in the Dairy Cattle Populations of Ukrainian Selection
}

\author{
Roman Kulibaba $^{1 *}$, Yuriy Liashenko², Polina Yurko ${ }^{3}$, Mykola Sakhatskyi ${ }^{1}$, \\ Yulia Osadcha ${ }^{1}$ \& Hamza Alshamaileh ${ }^{1}$ \\ ${ }^{1}$ National University of Life and Environmental Sciences of Ukraine, Heroyiv Oborony st., \\ 15, Kyiv, 03041, Ukraine ${ }^{2}$ Institute of Animal Science, the National Academy of Agrarian \\ Sciences of Ukraine, 1-A, Tvarynnykiv Str., Kharkiv, 61026, Ukraine ${ }^{3}$ Kharkiv State \\ Zooveterinary Academy of the Ministry of Education of Science of Ukraine, 1, \\ Akademichna Str., Smt Mala Danylivka, 62341, Ukraine \\ *Corresponding author e-mail: romankx37@gmail.com
}

Received 29 November 2020; Accepted, 30 January 2020; Available online 23 February 2021

\begin{abstract}
Study was conducted by investigating the genetic structure of cattle populations of Ukrainian Black-and-White and Ukrainian Red-and-White dairy breeds by polymorphism of leptin gene $(L E P)$ and tumor necrosis factor-alpha gene $(T N F-\alpha)$. The studies were carried out using the method of polymerase chain reaction (PCR) and restriction analysis for $L E P$ and using classic PCR with subsequent SSCP analysis in case of $T N F-\alpha$. According to the results of the study, it was shown that the LEP gene was polymorphic in both experimental populations by HphI-polymorphism in the third exon of the gene (A59V mutation). In the population of the Ukrainian Black-and-White dairy cattle breed, the frequency of allele $\mathrm{C}(\mathrm{HphI}-)$ was 0.77 ; allele $\mathrm{T}(\mathrm{HphI}+)-0.23$. Wright's fixation index was 0.23; which indicates a significant excess in the number of homozygous individuals. This population had a deviation from the Hardy-Weinberg equilibrium state. In the population of the Ukrainian Red-and-White dairy breed, the frequency of allele $\mathrm{C}$ was 0.72; allele $\mathrm{T}-0.28$; Wright's fixation index was -0.18 . According to the SSCPpolymorphism of the TNF- $\alpha$ gene, 6 alleles with a size of 450-1200 bp were detected (alleles A, B, and F for Ukrainian Black-and-White dairy breed; A, B, C, D, E, F - for Ukrainian Red-and-White dairy breed). The frequency of allele A prevailed in the populations of both breeds (0.58 and 0.54, respectively). Alleles C, D, and E had a low frequency of occurrence (0.04-0.16) and they were found only in the population of Redand-White dairy breed.

Keywords: alleles; genetic diversity; mastitis; PCR-RFLP; SSCP; cattle.
\end{abstract}

\section{Introduction}

For the last decades, livestock was one of the fastest-growing sectors of the world's economy. Dairy cattle breeding plays an important role in ensuring the population's food security among the entire agro-industrial complex. However, despite all the advantages and perspectives, the 
successful implementation of livestock development programs are complicated by several factors, one of which is related to the problem of animal diseases (Hogeveen \& Van Der Voort, 2017).

In dairy cattle breeding, on the background of an ever-increasing level of milk production in the world, one of the most common diseases is mastitis (Mesquita et al., 2012; Gomes \& Henriques, 2016). Along with the positive dynamics in the productivity of cows, the level of disease with mastitis also increases. Thus, according to literary sources, the disease is diagnosed in $48 \%$ of the world, while in the European Union the number of clinically sick animals is about $30 \%$ of the total dairy herd. This problem is also typical of Ukraine (Mass et al., 2016; Panevnyk \& Suprovych, 2016).

Mastitis is a serious cause of economic losses in animal cattle breeding (Chopra et al., 2015). This disease causes significant economic losses to dairy cattle breeding due to a decrease in milk production and the risk of increasing the sickness of young animals, deterioration in the quality of milk and dairy products (Seegers et al., 2003). Accordingly, the amount of economic costs for mastitis includes the costs of treatment and the implementation of preventive measures and depends on the stage of the inflammatory process. It should be noted that in highly productive animals that have suffered mastitis, productivity does not fully recover. Moreover, this disease should be considered not only as an economic and veterinary problem but also as unsafe for human health (Hameed et al., 2006). Thus, mastitis is recognized as one of the priority problems of veterinary medicine in cattlebreeding practice, due to its widespread, significant economic losses, and the sanitary threat to humans.

The causes of mastitis are very different, so the disease is related to polyethiological ones (Litwinczuk et al., 2015; Abebe et al., 2016). The subclinical form of the disease is the most widespread (Zainettinova et al., 2019). Along with the widely known and common methods of the prevention and control of mastitis, researches aimed at studying the genetic aspects associated with this disease has become more widespread (Mulder et al., 2011; Kurtz et al., 2018).

First of all, we mean the study of genetic factors associated with the immunity (resistance) of various breeds and lines of animals (Sender et al., 2013). In the context of the ongoing marker-assisted selection (MAS), various candidate genes which allelic variants are associated with animal resistance to mastitis are studied. Additionally, researches are conducted aimed at studying the productive traits of experimental animals in order to identify potential counterproductive alleles of various genes. There has been found several quantitative trait loci (QTL) associated with mastitis resistance. One of the promising candidate genes associated with mastitis resistance includes the leptin gene (LEP) and tumor necrosis factor $\alpha$ gene (TNF- $\alpha$ ).

Leptin is a peptide hormone that synthesized by adipose tissue (Daix et al., 2008). It takes part in the regulation of a large number of different organism's functions, primarily fat and energy metabolism, as well as in the regulation of the immune system activity and reproductive functions (Barb \& Kraeling, 2004).

The cattle leptin gene is located on the fourth 
chromosome and consists of three exons and two introns. As a rule, $L E P$ is considered as a candidate gene for markers of meat production (primarily as an indicator of live weight), as well as the indicators of milk quality (Yang et al., 2007). There are a lot of perspective mutations (in the terms of marker-assisted selection) in the leptin gene were discovered in the cattle populations of different breeds. First of all, there are many publications about associations between different allelic variants of the leptin gene and the parameters of growth, carcass, and meat quality traits of cattle (Wang et al., 2020). The investigations about polymorphism of the leptin gene are not only been connected with the parameters of meat productivity but also with the studies of milk production traits. Moreover, as well as commercial cattle breeds the studies also conducted for the local breeds and the buffalo. In the recent years, the studies have been carried out to explore the relationship between milk traits and leptin gene polymorphism in Autochthonous Busha Cattle (Maletic et al., 2019), Egyptian Buffalo (El-Debaky et al., 2020), etc.

The problems that have been tried to be solved also consider some veterinary aspects. For example, the scientific work of M.A. Ferchichi et al. (2018) studied the relationship between Sau3AI-polymorphism in the leptin gene and lameness prevalence in Tunisian Holstein cows. It should be noted the studies were carried out not only on cattle but also on sheep (Saleem et al., 2018), goat (Avondo et al., 2019), and last but not least, on the pig (Snegin et al., 2020) that indicates $L E P$ as one of the most interesting targets for the tasks of marker-assisted selection in livestock. Additionally, publications of various authors revealed an associative relation between different allelic variants of leptin and the somatic cell count in milk in different cattle breeds, which makes it a promising object in the context of researches regarding mastitis resistance (Kulig et al., 2010; Kiyici et al., 2019).

TNF- $\alpha$, a tumor necrosis factor-alpha, is a multifunctional anti-inflammatory cytokine, related to one of the key mediators of the local immune response (Kushibiki 2011). It takes part in the regulation of the activity of a large number of different genes of the immune system, stimulates the proliferation of lymphocytes, and initiates the synthesis of interleukins.

The TNF- $\alpha$ gene is located on the 23rd chromosome and contains about 30 polymorphic fragments. Various allelic variants have been identified according to their different positions of the gene, as well as their relation to productivity indicators and also to resistance/sensitivity to various diseases, including mastitis (Ranjan et al., 2015). There is no investigation about features of the genetic structure by TNF- $\alpha$ gene polymorphism in the cattle population of Ukrainian selection.

Considering all of the above, the aim of our work was the study of the polymorphism of LEP and TNF- $\alpha$ genes in the dairy cattle populations of Ukrainian Black-and-White and Ukrainian Red-and-White breeds.

\section{Materials \& Methods}

Dairy cattle breeds of Ukrainian selection, Ukrainian Black-and-White dairy breed ( $\mathrm{n}=$ 100) and Ukrainian Red-and-White dairy breed $(\mathrm{n}=100)$ were used in the present study. 
The study was carried out in the laboratory of molecular-genetic and physiologicalbiochemical research in animal science of the Institute of Animal Science of the NAAS. Experienced groups of cows were kept in the experimental farm "Hontarovka" (Vovchansk district, Kharkov region).

DNA was extracted using a commercial DNA-Sorb-B reagent kit (Amplisens, Russian Federation), according to the manufacturer's instructions. Hair follicles were used as a DNA source. The DNA extraction efficiency was determined by agarose electrophoresis $(0.7 \%)$.

For each sample, the reaction was carried out using specific primers flanking the corresponding gene fragment, which potentially contains a polymorphic site.

Using the PCR-RFLP method, HphIpolymorphism in the third exon of the LEP gene was studied $(\mathrm{C} / \mathrm{T}$ transition, A59V mutation). The following primers were used for amplification:

GGGAAGGGCAGAAAGATAG

and TGGCAGACTGTTGAGGATC (Haegeman et al., 2000).

In both cases, amplification was performed with a DreamTaq PCR Master Mix kit (Thermo Scientific) using appropriate standard programs. The volume of the final PCR mixture was $10 \mu \mathrm{l}$. The concentrations of each primer (forward and reverse) were $0.2 \mu \mathrm{M}$.

The annealing temperature is $56^{\circ} \mathrm{C}$. The size of the amplified fragment is $331 \mathrm{bp}$. The restriction was performed using restriction endonuclease HphI according to the manufacturer's (Thermo Scientific) protocol. HphI-polymorphism of the locus leads to the creation of a restriction site and, accordingly, to the appearance of two restriction fragments of 311 and $20 \mathrm{bp}$.

Amplificated products were separated by $1.5 \%$ agarose gel $(150 \mathrm{~V}$ for $30 \mathrm{~min})$ in TBE buffer. Visualization was carried out with ethidium bromide (UV light).

The sizes of restriction fragments were determined using molecular weight markers M50 (InterLabService, AmpliSens ${ }^{\circledR}$ Biotechnologies, Russia). We used the single 284 bp DNA-fragment as an additional molecular weight marker as well.

The TNF- $\alpha$ gene polymorphism was studied by the PCR-SSCP method. Amplification was performed using primers: TACTGCTTCCATCCCTTGAC and GAGAAGACAAGACCCATCAG (Ranjan et al., 2015).

The amplified gene fragment contains a part of intron 1, exon 2, and a part of intron 2. The temperature of the primer annealing is $55{ }^{\circ} \mathrm{C}$. The size of the amplified fragment is $239 \mathrm{bp}$. After amplification, electrophoresis was performed to detect SSCP polymorphism according to the appropriate technique (Barroso et al., 1998).

Amplificated products were separated by 8 $12 \%$ polyacrylamide gels with a different value of the glycerol component (2-10\%) at 300-350 V for 180-300 min in TBE buffer. The samples were stained according to the silver staining protocol (Sambrook \& Russell 2001).

The main parameters of the genetic structure of the experimental populations were determined using standard techniques and appropriate software. Allele frequencies were determined by the formulas of maximum likelihood according to E.K. Merkur'eva (1977). Basing 
on the obtained frequencies of alleles and genotypes, the observed $\left(\mathrm{H}_{\mathrm{o}}\right)$ and expected $\left(\mathrm{H}_{\mathrm{e}}\right)$ heterozygosity, the effective number of alleles $\left(\mathrm{n}_{\mathrm{e}}\right)$, the Wright's fixation index $\left(\mathrm{F}_{\mathrm{is}}\right)$, and the correspondence to the state of genetic equilibrium according to Hardy-Weinberg (with using the $\chi^{2}$ method) were determined according to standard techniques with the use of the Popgen32 software (https://sites.ualberta.ca/ fyeh/popgene_download.html).

\section{Results \& Discussion}

The use of restriction analysis made it possible to identify the variability of the leptin gene in experimental cattle populations (Fig. 1).

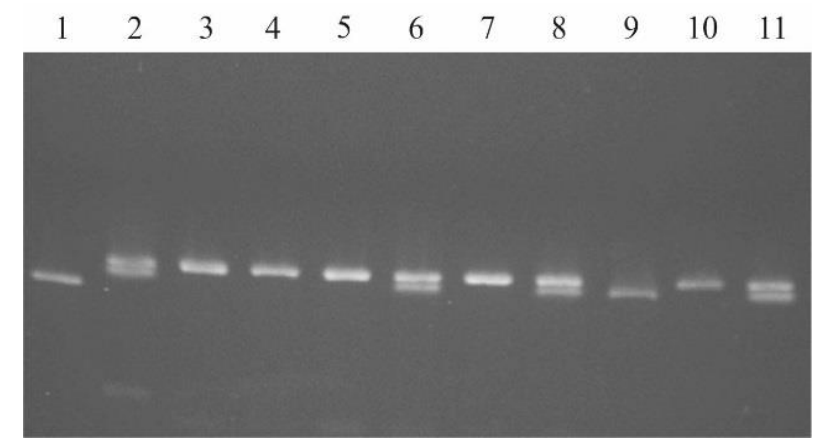

Fig. (1): LEP gene polymorphism (HphIpolymorphism in the third exon) in the dairy cattle populations. 1 - single molecular weight marker $(284$ bp); 2, 6, 8, 11 genotype $\mathrm{C} / \mathrm{T}$; 3-5, 7, 10 - C/C; 9 - T/T

Allelic variants of the LEP gene resulting from HphI-polymorphism in the third exon of the gene are shown on the electrophoregram of restriction fragments.

As follows from the research results, the leptin gene is polymorphic in both experimental populations. In each population, individuals of all possible genotypes $(\mathrm{C} / \mathrm{C}, \mathrm{C} / \mathrm{T}, \mathrm{T} / \mathrm{T})$ are identified (Fig. 1).

The genetic structure of the experimental animal populations by the LEP locus is presented in table (1).

Table (1): Genetic structure of dairy cattle populations of Ukrainian selection (mutation A59V).

\begin{tabular}{lllllll}
\hline \multirow{2}{*}{\begin{tabular}{l} 
Populatio \\
\cline { 2 - 5 }
\end{tabular}} & \multicolumn{2}{c}{ Genotype } & \multicolumn{3}{c}{ Allele } & \multirow{2}{*}{$\chi^{2}$} \\
\cline { 2 - 5 } & CC & CT & TT & C & T & \\
\hline $\begin{array}{l}\text { Black- } \\
\text { and- } \\
\text { White }\end{array}$ & 0.6 & 0.2 & 0.0 & 0.7 & 0.2 & 4.9 \\
\hline $\begin{array}{l}\text { Red-and- } \\
\text { White }\end{array}$ & 0.4 & 0.4 & 0.0 & 0.7 & 0.2 & 2.4 \\
& 8 & 7 & 5 & 2 & 8 & 2 \\
\hline
\end{tabular}

According to the ratio of the frequencies of LEP genotypes, the experimental populations differ considerably from each other.

The population of the Ukrainian Black-andWhite dairy breed is characterized by a significant prevalence of the number of individuals of the $\mathrm{CC}$ genotype, while such a trend was not observed in the population of the Ukrainian Red-and-White dairy breed (Table 1). In the population of the Ukrainian Blackand-White dairy breed, the frequency of allele C (HphI-) was 0.77; allele T (HphI+) was 0.23. The value of the observed and expected heterozygosity was 0.27 and 0.35 , respectively. Wright's fixation index was 0.23 ; which indicates a significant excess of homozygous individuals. In its turn, in the population of Red-and-White dairy breed, the frequency of allele $\mathrm{C}$ was 0.72 ; allele $\mathrm{T}$ was 0.28 ; the 
observed and expected heterozygosity was 0.47 and 0.40 ; Wright's fixation index was -0.18 ; which indicates an expressed excess in the number of heterozygous individuals and population was in the state of genetic equilibrium. In the Black-and-White Ukrainian cow's population, a deviation from the state of genetic equilibrium was noted $\left(\chi^{2}=4.97 ; \mathrm{p}\right.$ $<0.05)$. In terms of the effective number of alleles, the population of the Red-and-White dairy breed is characterized by a large value 1.66 as against the value of 1.54 in the Blackand-White dairy breed.

The results obtained in this research on the frequency values of the alleles of the leptin gene (mutation A59V) are consistent with the results of other authors. Similar gene frequencies were obtained by Liefers et al. (2003) in Holstein-Friesian cattle, Clempson et al. (2011) in Holstein cattle, Yazdani et al. (2010) in Iranian cattle and Silva et al. (2012) in Indian cattle. Abbas et al. (2019) and Maletic et al. (2019) also noted the predominance of the frequency of the $\mathrm{C}$ allele, up to a monomorphic state, in Pakistan and Balkan cattle. The observed pattern might be explained by the influence of the ongoing selection program in the direction of increasing milk production, as well as by the stochastic genetic factors (genetic drift).

Work has been done on optimizing the technique of SSCP analysis for genotyping by the locus of tumor necrosis factor-alpha (TNF$\alpha$ ). According to the research results it was shown that for effective genotyping the $12 \%$ polyacrylamide gels (acrylamide/bisacrylamide ratio 100/1) with a glycerol content of 5\% should be used, the temperature of the buffer used during electrophoresis should be $4-12{ }^{\circ} \mathrm{C}$; electric field parameters $-300-350 \mathrm{~V}$ during 4 hours. Silver staining was used to visualize amplified TNF- $\alpha$ fragments (Sambrook \& Russell, 2001).

The Use of the optimized technique of SSCP analysis made it possible to separate single and double-stranded DNA fragments efficiently (Fig. 2).

The electrophoregram (silver staining) of the amplification products of the second exon of the TNF- $\alpha$ gene is presented in fig. (3).

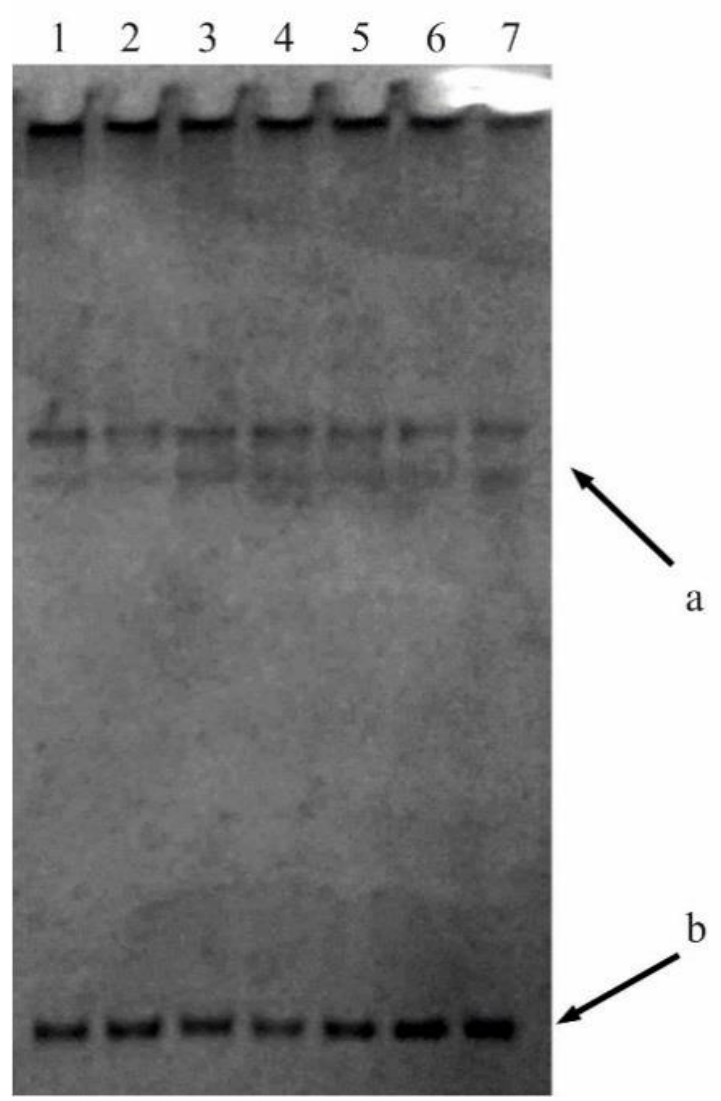

Fig. (2): SSCP-polymorphism in the TNF- $\alpha$ gene in the dairy cattle populations. a single stranded DNA fragments; $b$ - doublestranded DNA fragments. 


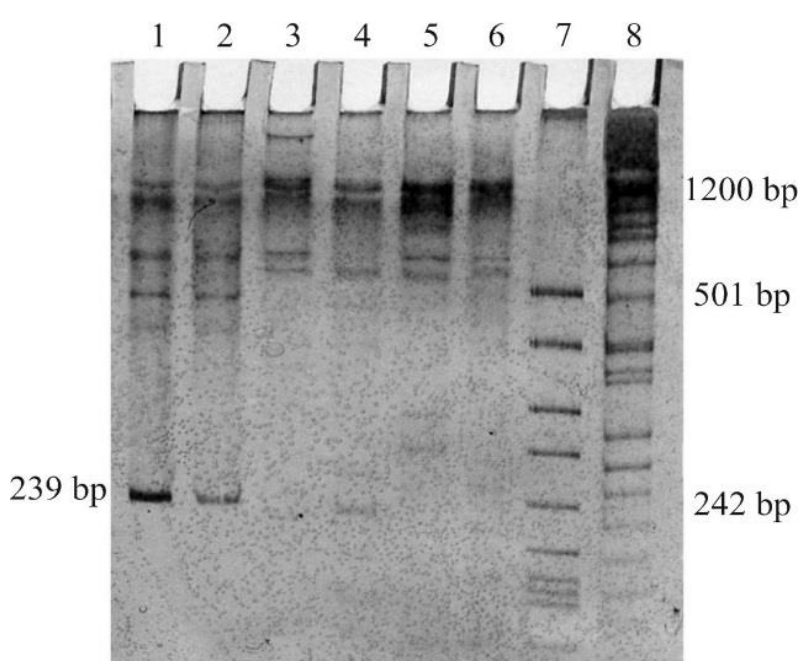

Fig. (3): Electrophoregram of the SSCPpolymorphism in the second exon of the TNF- $\alpha$ gene in the dairy cattle populations. 1 - AE; 2 - AF; 3 - AB; 4 - AC; 5 - AD; 6 AB; 7 - Molecular ladder 1; 8 - Molecular ladder 2.

According to the results of the analysis of single-chain patterns of the $T N F-\alpha$ gene region, 239 bp (second exon), 6 alleles were detected with a size of 450-1200 bp. Alleles A, B, and F were found in the population of the Ukrainian Black-and-White dairy breed, and alleles A, B, C, D, E, F were found in the population of the Ukrainian Red-and-White dairy breed. The genotypes of both breeds the frequency of allele A was 0.58 and 0.54 , respectively. Alleles C, D, and $\mathrm{E}$ had a low frequency of occurrence (0.040.16 ) and were detected only in the Black-andWhite breed. Homozygous genotypes in both populations were only for the A allele.

The frequencies of genotypes and alleles by SSCP polymorphism of the second exon of the $T N F-\alpha$ gene in both experimental cattle populations are presented in table (2).
The Ukrainian Red-and-White dairy breed, in the present study, show a significantly higher level of polymorphism of the $T N F-\alpha$ locus in terms of the number of identified alleles and the corresponding genotypes. However, despite the differences in the number of alleles and genotypes, the frequencies of the most prevailing allele in both populations practically coincide -0.58 versus 0.54 , respectively, which may be a consequence of the general orientation of the ongoing selection program toward the increasing of milk yield.

Table (2): Genotype and allele frequencies in the dairy cattle populations by SSCPpolymorphism in the $T N F-\alpha$.

\section{Population}

\begin{tabular}{l|l}
\hline $\begin{array}{l}\text { Ukrainian Black-and- } \\
\text { White dairy breed }\end{array}$ & $\begin{array}{l}\text { Ukrainian Red-and- } \\
\text { White dairy breed }\end{array}$ \\
\hline
\end{tabular}

Genotype

\begin{tabular}{l|l}
\hline $\mathrm{AA}-0.16 ; \mathrm{AB}-$ & $\mathrm{AA}-0.08 ; \mathrm{AB}-0.12 ;$ \\
$0.32 ;$ & $\mathrm{AC}-0.2 ; \mathrm{AD}-0.32 ;$ \\
$\mathrm{AF}-0.52$ & $\mathrm{AE}-0.08 ; \mathrm{AF}-0.2$ \\
\hline
\end{tabular}

Allele

\begin{tabular}{l|l}
$\mathrm{A}-0.58 ; \mathrm{B}-0.16 ; \mathrm{F}$ & $\mathrm{A}-0.54 ; \mathrm{B}-0.06 ; \mathrm{C}-$ \\
-0.26 & $0.1 ; \mathrm{D}-0.16 ; \mathrm{E}-0.04$ \\
& $\mathrm{~F}-0.1$
\end{tabular}

As it was already noted, the $T N F-\alpha$ locus under study contains the second exon (49 bp, http://www.ensembl.org) and adjacent sections of 1 and 2 introns (190 bp). According to the Ensembl database in the second exon of $T N F-\alpha$, 4 SNPs were identified: rs451672471 (A/G, 
synonymous variant), rs456866435 (C/T, synonymous variant), $\quad$ rs110320728 (T/C, synonymous variant), and rs469370538 (G/C, synonymous variant). Therefore, the present results fully agree with the likelihood of the correspondence of different polymorphic variants to the different SSCP patterns revealed. In addition, the intron region of the locus, on which there is no information about SNP, can add additional patterns (variants). In general, we found 6 different SSCP patterns -3 in the Ukrainian Black-and-White population and 6 in the Red-and-White dairy breed (two of which were found at a low frequency (0.04-0.06). For comparison, 2 SSCP patterns, alleles A and B with frequencies of 0.73 and 0.27 (Ranjan $e t$ al., 2015), were revealed in a crossbreeding Indian cattle population (Holstein-Frisian $x$ brown Swiss $\times$ jersey). Based on an example of a study of two groups of cows with different infectious loads, the authors suggest that the A allele is mainly found among individuals sensitive to mastitis. In addition, the expression of mRNA of $T N F-\alpha$ is significantly higher in cows with the $\mathrm{AA}$ genotype compared to $\mathrm{AB}$ and $\mathrm{BB}$, which suggests the use of the obtained SSCP-patterns as possible markers of mastitis resistance in dairy cattle. Unfortunately, the authors of this article do not provide data on the size of the alleles; therefore, we can only assume that the more widespread and slowly migrating DNA strands (allele A) in the population correspond to the SSCP pattern A that we found (1200 bp) in Ukrainian cattle populations.

\section{Conclusion}

The genetic structure specificities of cattle populations of Ukrainian Black-and-White and Red-and-White dairy breeds by leptin gene and tumor necrosis factor-alpha gene were studied. According to the research results, the frequency of occurrence of the allele $\mathrm{C}$ significantly prevails at the leptin locus in both populations. Moreover, a deviation from the equilibrium state according to Hardy-Weinberg was noted in the population of the Black-and-White dairy breed. The TNF- $\alpha$ locus in both populations also showed a predominance of the frequency of occurrence of the allele A. Considering the high level of polymorphism of the studied locus, as well as its potential in regulating the body's immune system, further studies are promising and will be carried out in the direction of studying the relation of various allelic variants of $T N F-\alpha$ with economically desirable traits of cattle populations. Also it is planned to analyze the nucleotide sequences of the identified allelic variants of $T N F-\alpha$.

\section{Conflict of interest}

The authors declare that they have no conflict of interest.

Ethical approval: all applicable national and international guidelines for the care and use of animals were followed.

\section{Acknowledgements}

The authors thank to the Laboratory of molecular-genetic and physiologicalbiochemical research in animal science staff, Institute of Animal Science of the National Academy of Agrarian Sciences of Ukraine.

\section{ORCID}

R. Kulibaba: 0000-0003-1776-7147

Yu. Liashenko: 0000-0003-2747-476X

P. Yurko: 0000-0003-4870-1570

M. Sakhatskyi: 0000-0002-6113-0226 


\section{Kulibaba et al., / Basrah J. Agric. Sci., 34(1): 180-191, 2021}

Yu. Osadcha: 0000-0003-4126-2456

H. Alshamaileh: 0000-0002-4757-8585

\section{References}

Abbas, N., Suleman, M., Zahur, A. B., Ghafoor, A., Rashid, F., Jan, A. U., Akbar, F., Ali, S., Aziz, A., Islam, Z., \& Shah, A. (2019). Molecular Analysis of Leptin Gene Polymorphism in Achai, Sahiwal Cattle and Nili-ravi Buffalo Breeds of Pakistan. International Journal of Genetics and Genomics, 7, 75-79. http://doi:10.11648/j.ijgg.20190703.17

Abebe, R., Hatiya, H., Abera, M., Megersa, B., \& Asmare, K. (2016). Bovine mastitis: prevalence, risk factors and isolation of Staphylococcus aureus in dairy herds at Hawassa milk shed, South Ethiopia. BMC Veterinary Research, 12, 270. http://doi:10.1186/s12917-016-0905-3

Avondo, M., Di Trana, A., Valenti, B., Criscione, C., Bordonaro, S., De Angelis, A., Giorgio, D., \& Di Gregorio, P. (2019). Leptin gene polymorphism in goats fed with diet at different energy level: Effects on feed intake, milk traits, milk fatty acids composition, and metabolic state. Animals, 9, 424. http://doi:10.3390/ani9070424

Barb, C. R., \& Kraeling, R. R. (2004). Role of leptin in the regulation of gonadotropin secretion in farm animals. Animal Reproduction Science, 82-83, 155167. http://doi:10.1016/j.anireprosci.2004.04.032

Barroso, A., Dunner, S., \& Canon, J. (1998). Technical note: Detection of bovine kappa-casein variants $\mathrm{A}$, $\mathrm{B}, \mathrm{C}$, and $\mathrm{E}$ by means of polymerase chain reactionsingle strand conformation polymorphism (PCRSSCP). Journal of Animal Science, 76, 1535-1538. http://doi:10.2527/1998.7661535x

Chopra, A., Gupta, I. D., Verma, A., Chakravarty, A. K., \& Vohr, V. (2015). Lactoferrin gene promoter variants and their association with clinical and subclinical mastitis in indigenous and crossbred cattle. Polish Journal of Veterinary Sciences, 18, 465-471. http://doi:10.1515/pjvs-2015-0061

Clempson, A. M., Pollott, G. E., Brickell, J. S., Bourne, N. E., Munce, N., \& Wathes, D. C. (2011). Evidence that leptin genotype is associated with fertility, growth, and milk production in Holstein cows.
Journal of Dairy Science, 94, 3618-3628. http://doi:10.3168/jds.2010-3626

Daix, M., Pirotte, C., Bister, J. L., Wergifosse, F., Cuvelier, C., Cabaraux, J. F., Kirschvink, N., Istasse, L., \& Paquay, R. (2008). Relationship between leptin content, metabolic hormones and fat deposition in three beef cattle breeds. The Veterinary Journal, 177, 273-268. http://doi:10.1016/j.tvj1.2007.04.004

El-Debaky, H., Mahmoud, K. M., Abd El-Razik, K. A., Sosa, A. S. A., Kandiel, M. M. M., \& Ahmed, Y. F. (2020). PCR-SSCP and sequencing analysis for studying Leptin gene polymorphism and its association with reproductive status of Egyptian Buffalo. Egyptian Journal of Veterinary Sciences, 51, 11-21. http://doi:10.21608/ejvs.2019.16438.1094

Ferchichi, M. A., Jemmali, B., Amiri, S., Gara, A. B., \& Rekik, B. (2018). Effect of leptin genetic polymorphism on lameness prevalence in Tunisian Holstein cows. Archives Animal Breeding, 61, 305310. http://doi:10.5194/aab-61-305-2018

Gomes, F., \& Henriques, M. (2016). Control of Bovine Mastitis: Old and recent therapeutic approaches. Current Microbiology, 72, 377-382. http://doi:10.1007/s00284-015-0958-8

Haegeman, A., Van Zeveren, A., \& Peelman, L. J. (2000). New mutation in exon 2 of the bovine leptin gene. Animal Genetics, 31, 79. http://doi:10.1111/j.1365-2052.2000.579-14.x

Hameed, K. G. A., Sender, G., \& Korwin-Kossakowska, A. (2006). Public health hazard due to mastitis in dairy cows. Animal Science Papers and Reports, 25, 73-85.

Hogeveen, H., \& Van Der Voort, M. (2017). Assessing the economic impact of an endemic disease: the case of mastitis. Revue scientifique et technique (International Office of Epizootics), 36, 217-226. http://doi:10.20506/rst.36.1.2623

Kiyici, J. M., Akyüz, B., Kaliber, M., Arslan, K., Aksel, E. A., \& Çinar, M. U. (2019). LEP and SCD polymorphisms are associated with milk somatic cell count, electrical conductivity and $\mathrm{pH}$ values in Holstein cows. Animal Biotechnology, 31, 498503.http://doi:10.1080/10495398.2019.1628767 


\section{Kulibaba et al., / Basrah J. Agric. Sci., 34(1): 180-191, 2021}

Kulig, H., Kmiec, M., \& Wojdak-Maksymiec, K. (2010). Associations between Leptin Gene Polymorphisms and Somatic Cell Count in Milk of Jersey Cows. Acta Veterinaria Brno, 79, 237-242. http://doi:10.2754/avb201079020237

Kurtz, J. P., Yang, Z., Weiss, R. B., Wilson, D. J., Rood, K. A., Liu, G. E., \& Wang, Z. (2018). A genomewide association study for mastitis resistance in phenotypically well-characterized Holstein dairy cattle using a selective genotyping approach. Immunogenetics, $\quad 71, \quad 35-47$. http://doi:10.1007/s00251-018-1088-9

Kushibiki, S. (2011). Tumor necrosis factor- $\alpha$-induced inflammatory responses in cattle. Animal Science Journal, 82, 504-511. http://doi:10.1111/j.17400929.2011.00931.x

Liefers, S. C., Pas, M. F. W., Veerkamp, R. F., Chilliard, Y., Delavaud, C., Gerritsen, R., \& Lende, T. (2003). Association of leptin gene polymorphisms with serum leptin concentration in dairy cows. Mammalian Genome, 14, 657-663. http://doi:10.1007/s00335-003-2275-y

Litwinczuk, Z., Krol, J., \& Brodziak, A. (2015). Factors determining the susceptibility of cows to mastitis and losses incurred by producers due to the disease a review. Annals of Animal Science, 15, 819-831. http://doi:10.1515/aoas-2015-0035

Maletic, M., Paprikic, N., Lazarevic, M., Hodzic, A., Davidovic, V., Stanisic, L., \& Stanimirovic, Z. (2019). Insight in leptin gene polymorphism and impact on milk traits in autochtonous Busha cattle. Acta Veterinaria-Beograd, 69, 153-163. http://doi:10.2478/acve-2019-0012

Mass, A, Ovcarenko, G., \& Vaseska, A. (2016). The effectiveness of diagnosis and therapy cow's with mastitis. Scientific Messenger of Lviv National University of Veterinary Medicine and Biotechnologies named after S.Z. Gzhytskyj, 18, 101104.

Merkur'eva, E. K., (1977). Geneticheskie osnovy selektsii v skotovodstve [Genetic Basis of Breeding in stock raising]. Moscow]: Kolos. 240 pp. (In Russian).

Mesquita, A. Q., Rezende, C. S. F., Jose de Mesquita, A., Garcia da Veiga Jardim, E. A., \& Kipnis A. P. J.
(2012). Association of TLR4 polymorphisms with subclinical mastitis in Brazilian Holsteins. Brazilian Journal of Microbiology, 43, 692-697. http://doi:10.1590/S1517-83822012000200034

Mulder, H. A., Lidauer, M. H., Vilkki, J. H., Stranden, I., \& Veerkamp, R. F. (2011). Marker-assisted breeding value estimation for mastitis resistance in Finnish Ayrshire cattle. Journal of Dairy Science, 94, 41644173. http://doi:10.3168/jds.2010-4112

Panevnyk, V., \& Suprovych, T. (2016). Etiological factors mastitis cows Ukrainian black-pied dairy breed. Scientific Messenger of Lviv National University of Veterinary Medicine and Biotechnologies named after S.Z. Gzhytskyj, 18, 191195. http://doi:10.15421/nvlvet7046

Ranjan, S., Bhushan, B., Panigrahi, M., Kumar, A., Deb, R., Kumar, P., \& Sharma, D. (2015). Association and Expression Analysis of Single Nucleotide Polymorphisms of Partial Tumor Necrosis Factor Alpha Gene with Mastitis in Crossbred Cattle. Animal Biotechnology, 26, 98-104. http://doi:10.1080/10495398.2014.929582

Saleem, A.H., Javed, K., Babar, M.E., Hussain, T., Ali, A., Ali, A., Ahmad, N., Farooq, M.Z., \& Dawood, M. (2018). Association of Leptin Gene Polymorphism with Growth Rate in Lohi Sheep. Pakistan Journal of Zoology, 50, 1029-1033. http://doi:10.17582/journal.pjz/2018.50.3.1029.1033

Sambrook, J., \& Russell, R. W. (2001). Molecular cloning: A laboratory manual, 3rd ed. Cold spring harbor laboratory press, cold spring harbor, N.Y. 2344pp.

Seegers, H., Fourichon, C., \& Beaudeau, F. (2003). Production effects related to mastitis and mastitis economics in dairy cattle herds. Veterinary Research, 34, 475-491. http://doi:10.1051/vetres:2003027

Sender, G., Korwin-Kossakowska, A., Pawlik, A., Hameed, K. G. A., \& Oprzade J. (2013). Genetic basis of mastitis resistance in dairy cattle - A review. Annals of Animal Science, 13, 663-673. http://doi:10.2478/aoas-2013-0043

Silva, R. C. G., Ferraz, J. B. S., Meirelles, F. V., Eler, J. P., Balieiro, J. C. C., Cucco, D. C., Mattos, E. C., 


\section{Kulibaba et al., / Basrah J. Agric. Sci., 34(1): 180-191, 2021}

Rezende, F. M., \& Silva, S. L. (2012). Association of leptin and leptin receptor genes with growth and ultrasound carcass traits in Nellore cattle. Genetics and Molecular Research, 11, 3721-3728. http://doi:10.4238/2012.August.17.10

Snegin, E. A., Artemchuk, O. Yu., Sychev, A. A., Barkhatov, A. S., Yusupov, S. R., Snegina, E. A., \& Tishchenko, A. Yu. (2020). Polymorphism in the leptin gene (T3469C) of Different Pig Breeds of the Belgorod Region of Russia. EurAsian Journal of BioSciences, 14, 3125-3129.

Wang, L., Raza, S. H. A., Gui, L., Li, S., Liu, X., Yang, X., Wang, S., Zan, L., \& Zhao, C. (2020). Associations between UASMS2 polymorphism in leptin gene and growth, carcass and meat quality traits of cattle: A meta-analysis. Animal Biotechnology,http://doi:10.1080/10495398.2020.18 05327

Yang, D., Chen, H., Wang, X., Tian, Z., Tang, L., Zhang, Z., Lei, C., Zhang, L., \& Wang, Y. (2007). Association of polymorphisms of leptin gene with body weight and body sizes indexes in Chinese indigenous cattle. Journal of Genetics and single nucleotide polymorphisms in the bovine Genomics, 34, 400-405. http://doi:10.1016/S16738527(07)60043-5

Yazdani, H., Rahmani, H. R., Edris, M. A., \& Dirandeh, E. (2010). Association between A59V polymorphism in exon 3 of leptin gene and reproduction traits in cows of Iranian Holstein. African Journal of Biotechnology, 9, 5997-6000. http://doi:10.5897/AJB10.126

Zainettinova, D. B., Muhamadieva, N. N., Julanov, M. N., Stefanyk, V. Yu., Zaviruha, V. V., \& Sarhambaeva, I. A. (2019). The effectiveness of the treatment of cows with mastitis. Scientific Messenger of Lviv National University of Veterinary Medicine and Biotechnologies. Series: Veterinary Sciences., 21, 78-81. http://doi:10.32718/nvlvet9414 
Kulibaba et al., / Basrah J. Agric. Sci., 34(1): 180-191, 2021

تعدد الطرز الشكلية لجينات LEP و TNF-a في مجتمعات ماشية الحليب الأوكرانية

رومان كوليبابا 1 * ، يوري لياثينكو 2 ، بولينا يوركو 33 ، ميكو لا ساكاتسكي 1 ،

يوليا أسدشا 1 وحمزة الثمايله 1

1الجامعة الوطنية للحياة والعلوم البيئية في أوكرانيا ، شارع هيروييف أوبوروني، 15، كييف، أوكرانيا

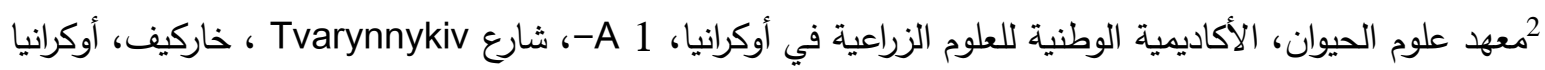

3 أكاديمية خاركيف الحكومية للحيوانات البيطرية التابعة لوزارة تعليم العلوم في أوكرانيا

المستخلص: نفذت الدراسة الحالية لتحديد التركيب الجيني في مانثية الحليب الأوكر انية من الهجائن الأبيض-و الأسود و الأحمر و

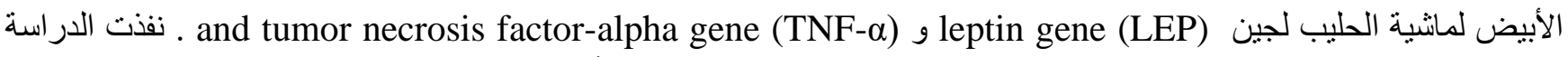

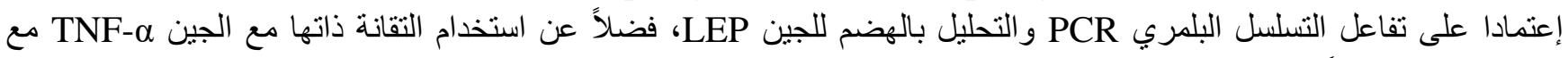

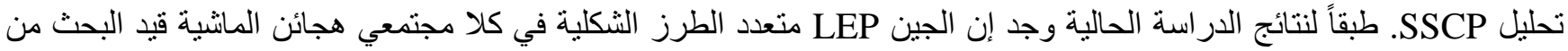

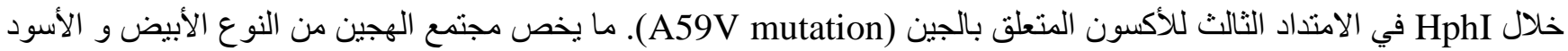

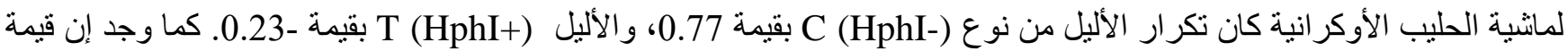

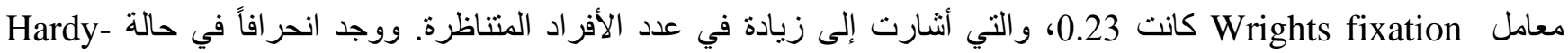
والإسل Weinberg equilibrium

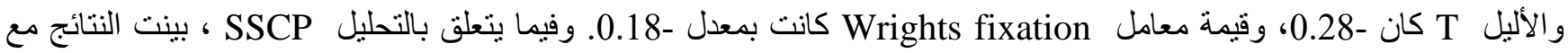

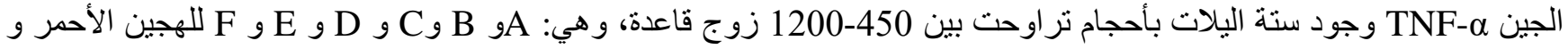

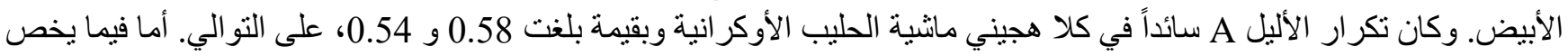

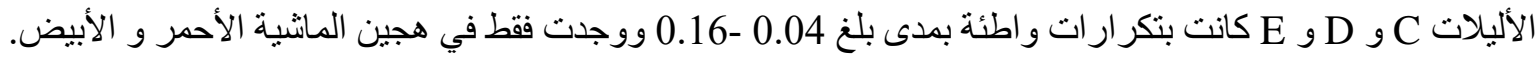

الكلمات المفتاحية: الاليلات ، التتوع الجيني، التهاب الضرع ، SSCP ، PCR-RFLP ، الماثنية. 